
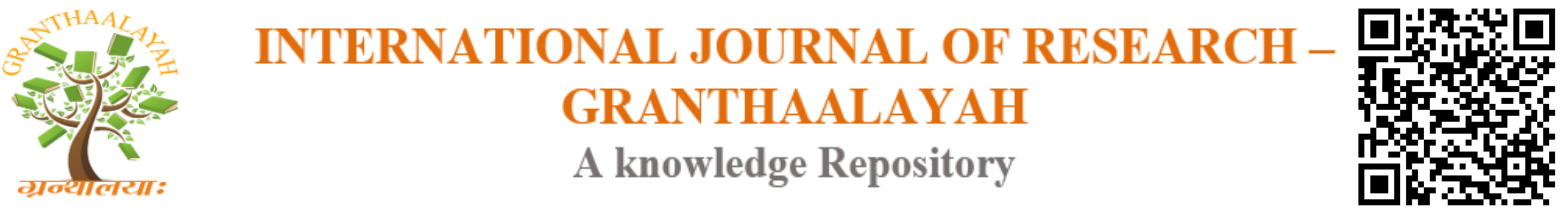

Science

\title{
COLLEMBOLA POPULATION AND DISTRIBUTION IN THE LITTER OF THREE TYPES OF LAND USED ON BUNGO DISTRICT JAMBI PROVINCE, INDONESIA
}

\author{
Febriyansyah $^{* 1}$, Jabang Nurdin ${ }^{2}$ \\ ${ }^{* 1,2}$ Department of Biology, Faculty of Mathematics and Natural Sciences, Andalas University, \\ 25163 West Sumatra, Indonesia
}

\begin{abstract}
The study had been conducted on February to July 2014. It was determined the population and distribution of Collembola on litter in the three types of land used, secondary forest, rubber plantation and oil palm plantation. This study was used belt quadrat methods with measure $25 \mathrm{x}$ $25 \mathrm{~cm} 2$. Generally, total individual of Collembola were found 248. Total Index diversity was 1.76.
\end{abstract}

Keywords: Bungo District; Collembola; Distribution; Litter; Population.

Cite This Article: Febriyansyah, and Jabang Nurdin. (2017). "COLLEMBOLA POPULATION AND DISTRIBUTION IN THE LITTER OF THREE TYPES OF LAND USED ON BUNGO DISTRICT JAMBI PROVINCE, INDONESIA.” International Journal of Research - Granthaalayah, 5(10), 17-22. https://doi.org/10.29121/granthaalayah.v5.i10.2017.2263.

\section{Introduction}

The litter is a place for decomposing where organism and microbe conduct it. It is also a place to food stockpile for organisms that live in the litter. One of the organisms that live in the litter area is Springtails (Suhardjono et al., 2012).

Collembola has act as decomposer that gives sustainability to the ground. Besides that, the act of Collembola is combined materials that decomposed from soil level to up surface level. So that, it will created a good fertility habitat. Barnes (1997) state that Collembola is an organism that able to process the combining organic material to soil surface level. Except that, Collembola is also an animal that accumulated with many organic materials (Ganjari, 2008).

The present of Collembola has wide spread to several lands, Bungo District in Jambi Province. This land is an area that happened rapidly change in it. For instance, forestland becomes rubber plantation and rubber plantation becomes oil palm plantation. After all, this study is conducted to know the population and distribution of Collembola in this area; also it is to know about the diversity of Collembola on litter in this area. 


\section{Materials and Methods}

This study had been conducted between February to July 2014 on the three types of land used (Secondary Forest, Rubber Plantation and Palm Oil Plantation) in Bungo District, Jambi Province, Indonesia. In each land, it was taken 6 point of samplings; there are two points at first border, two points at the middle and the others at the second border. Each point was repeated three times. This study was used belt transect with size $25 \times 25 \mathrm{~cm}^{2}$. The sampling collection was done with collecting the litter that in transect. Then, sample was put in plastic bag that had been labeled. After that, the sample was brought to lab for extracting using Barlese Tullgreen for 72 hours. The down side of the tool was put a thing that had been added alcohol $95 \%$. Next, the sample was filtered and divided into several groups, and then it was identified in Laboratorium of Animal Ecology, Faculty of Mathematics and Natural Sciences, University of Andalas. It also takes place in Laboratorium of Zoology, Indonesia Sciences Institute (LIPi), Indonesia. After that, the sample was calculated to find the diversity index value using formula after Magurran, 2004.

\section{Results and Discussions}

In general, Collembola on the three types of land used (Secondary forest, Rubber Plantation, and Oil Palm Plantation) is found 19 species that it belongs to into nine Families with total 248 Individuals. In general, the highest number of individual is Family Entomobryidae and species of Ascocyrtus sp., and the lowest number of individual is Family Sminthurididae with species Sphaeridia sp., (Table 1).

Based on the three types of land, the highest density in total is found on the secondary forest with $322,64 \mathrm{ind} / \mathrm{m}^{2}$, and oil palm plantation is the lowest density in total with $149,33 \mathrm{ind} / \mathrm{m}^{2}$. The high and low of density values on the three types of land is because the competition between predator and Collembola, also between Collembola itself with different species. Rizali et al., (2002) found that ant; "tungau", Coleoptera larvae and spiders are predator of Collembola. Besides that, present or absent of food sources give serious effect on density of Collembola (Jucevia and Maleis, 2005).

Based on the Family and Species numbers, the highest is Family Entomobryidae (Secondary Forest with 61,33 ind $/ \mathrm{m}^{2}$, Rubber Plantation with $85,33 \mathrm{ind} / \mathrm{m}^{2}$ and Oil Palm Plantation with $56,00 \mathrm{ind} / \mathrm{m}^{2}$ ) and species of Ascocyrtus sp. (secondary forest with $56,00 \mathrm{ind} / \mathrm{m}^{2}$, rubber plantation with $66,67 \mathrm{ind} / \mathrm{m}^{2}$ and oil palm plantation with $32,00 \mathrm{ind} / \mathrm{m}^{2}$ ). The high density of Ascocyrtus sp. is happened because the habitat is match for it to live. Even though, these species can be found on the different geographical area. Suhardjono et al., (2012) said that Family of Entomobryidae with the species of Ascocyrtus sp. was a species that can be found on wet habitat, has food source and different geographical areas.

The lowest density of Family and Species is on secondary forest with Family Oncopoduridae $2.67 \mathrm{ind} / \mathrm{m}^{2}$ and species of Oncopodura sp. $2.67 \mathrm{ind} / \mathrm{m}^{2}$. Rubber Plantation is found Family Cyphoderidae and Paronellidae with $2.67 \mathrm{ind} / \mathrm{m}^{2}$ each, also species of Cyphoderopsis sp. 2.67 ind $/ \mathrm{m}^{2}$, and Pseudoparonella sp. $2.67 \mathrm{ind} / \mathrm{m}^{2}$ ). Oil palm plantation is found Family Hypogastruridae with $5.34 \mathrm{ind} / \mathrm{m}^{2}$, spesies Ceratophysella sp. $2.67 \mathrm{ind} / \mathrm{m}^{2}$, and Xenylla sp. 2.67 
$\mathrm{ind} / \mathrm{m}^{2}$ (Table 1). Less numbers of food source in the nature, happening competition, and natural disaster like flood, and other different geographical area affects the low density of Family and Species. Suhardjono et al., (2012) said that Collembola is affected by the source of food in nature, the presenting of competition, the geographical of a habitat. Russel et al., (2004) also state natural disaster like flood is one of the factors that the decreased or extinguished of animal population like Collembola and other organisms. It will make stressed to organism for living. Besides that, it will also make the decreasing of mortality.

Table 1: Density (ind $/ \mathrm{m}^{2}$ ), Relative Density (\%), Frequency (\%) of Collembola was on the Litter in the three types of Lands at Bungo District, Jambi Province.

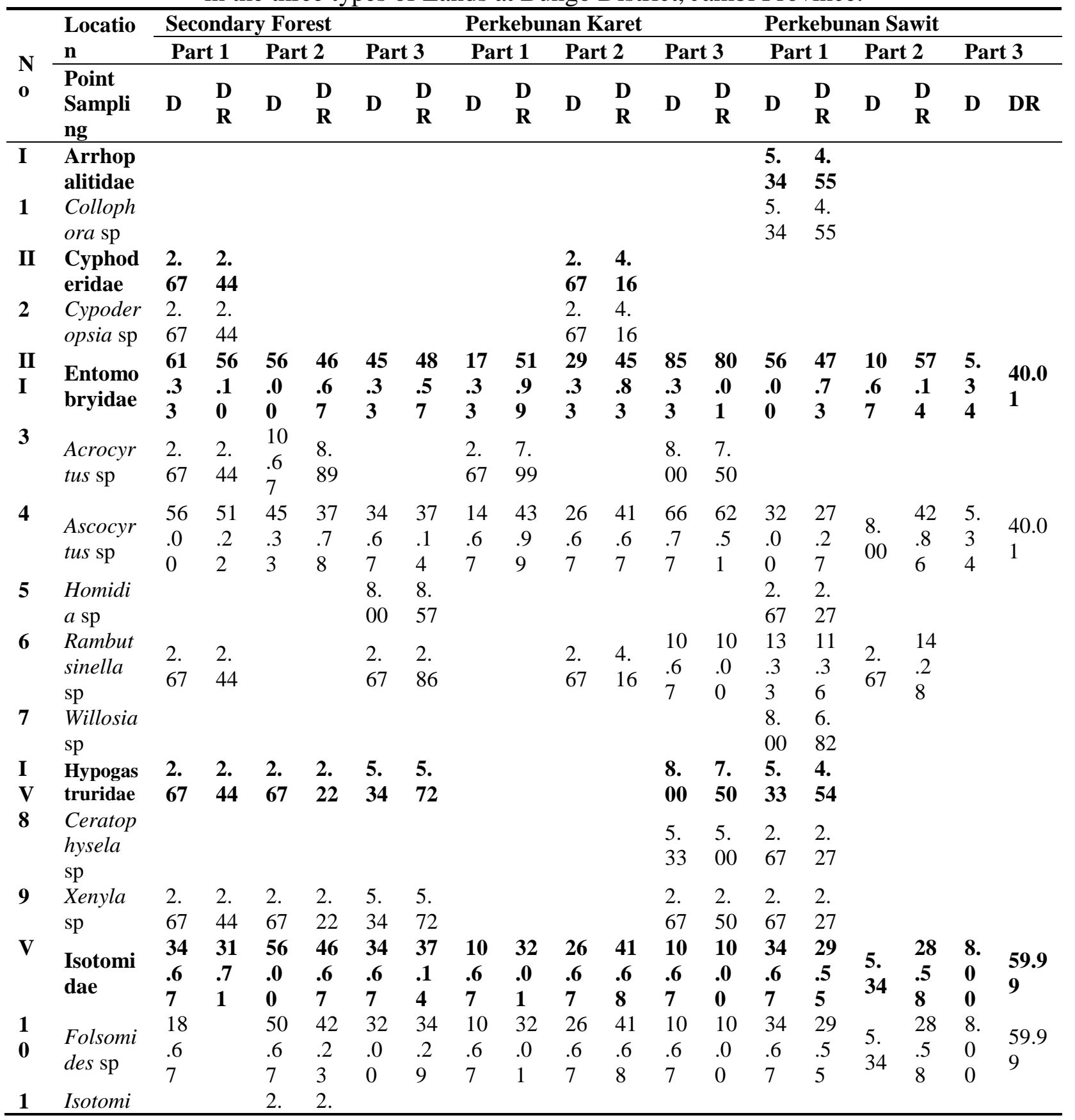




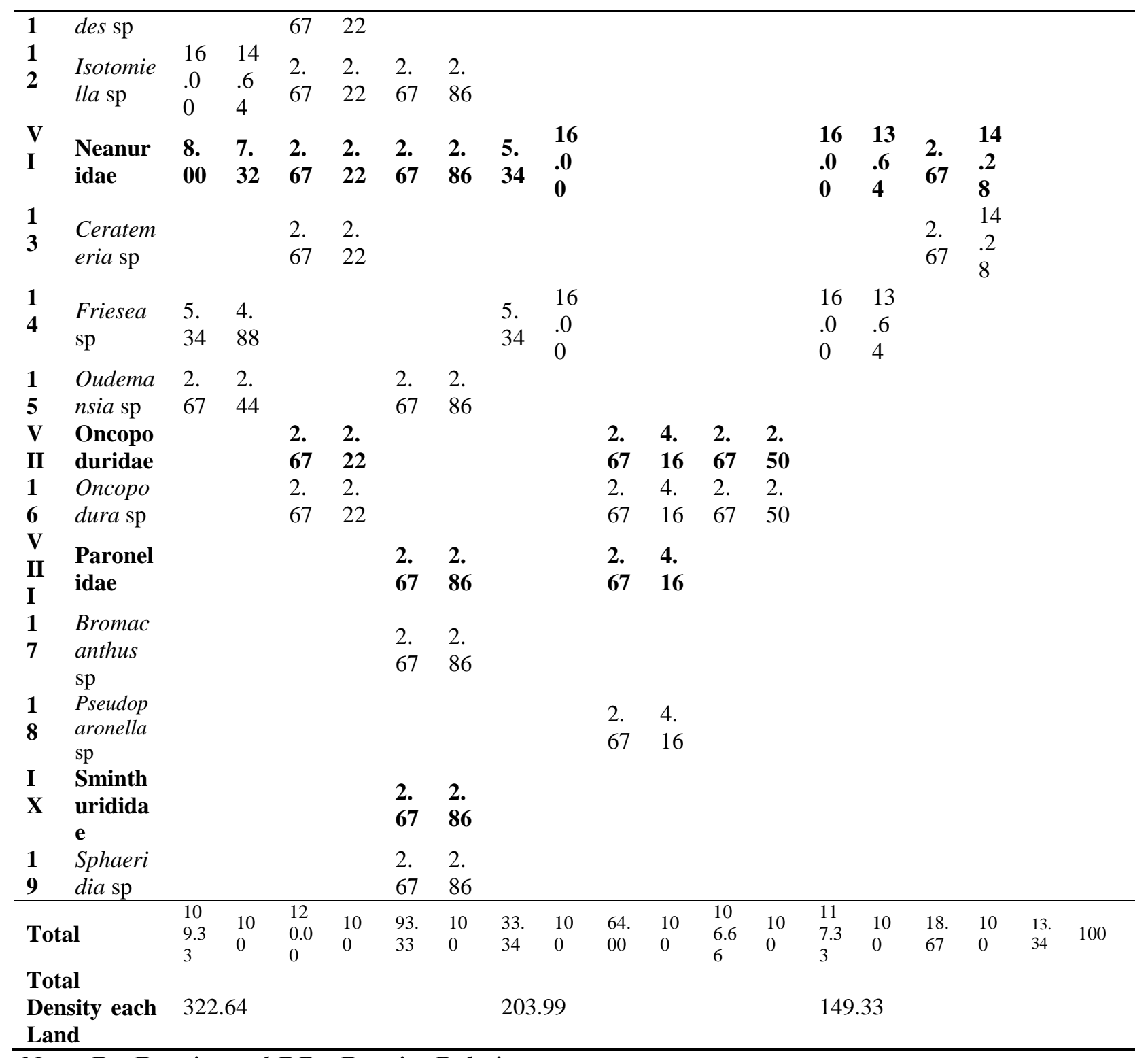

Note: $\mathrm{D}=$ Density and $\mathrm{DR}=$ Density Relative

Table 2: Diversity Index and Equitability Index of Collembola on the Litter at the three types of land used.

\begin{tabular}{llllll}
\hline \multirow{2}{*}{ Parameter } & \multicolumn{3}{l}{ The Land } & & \\
\cline { 2 - 5 } & Secondary Forest & $\begin{array}{l}\text { Rubber } \\
\text { Plantation }\end{array}$ & of & $\begin{array}{l}\text { Oil } \\
\text { Plantation }\end{array}$ & Palm \\
\hline H' & $1.54 \mathrm{a}$ & $1.48 \mathrm{a}$ & $1.77 \mathrm{a}$ & \\
E & 0.57 & 0.64 & 0.77 & \\
\hline
\end{tabular}

Note: using $t$ test with $95 \%$ of confidence level.

Diversity and Equitability Index of Collembola on the Litter are found that each land was diverse enough. Based on the diversity index test, it can be seen that the highest value was oil palm 
plantation with 1.77 and the lowest was rubber plantation with 1.48. However, According to criteria of diversity index value, these belong to medium level of diversity index.

Diversity of Collembola in this study is higher than Kebun Raya Unmul Samarinda is 0.92. (Trimurti, 2010). High and low of diversity index value are affected by the numbers of species and individual (odum, 1998). These can be proof that Collembola on Bungo District found 19 species with 9 Families and 248 Individuals at the litter. On the other hand, Kebun Raya Unmul Samarinda only found three families with 95 individuals of Collembola.

Equitability index of Collembola on Litter in the three types of land used is belongs to quite spreading. It can be proof that if the value of $E^{\prime}=0$ means the equitability each species is difference. When the $E^{\prime}=1$ means that the equitability of each species is quite same. (Magurran, 2004). In this study, all the equitability value is almost into one. It means these quite the same.

Table 3: Similarity Index of Collembola on Litter at three types of land used.

\begin{tabular}{lllll}
\hline Land Used & $\begin{array}{l}\text { Secondary } \\
\text { Forest }\end{array}$ & Rubber Plantation & $\begin{array}{l}\text { Oil } \\
\text { Plantation }\end{array}$ & Palm \\
\hline Secondary Forest & - & $68.84 \%$ & $39.35 \%$ \\
Rubber Plantation & - & - & $59.63 \%$ \\
Oil Palm Plantation & - & - & - & \\
\hline
\end{tabular}

Based on the similarity index of Collembola on Table 3, it clear that the high value of similarity index is found between secondary forest and rubber plantation with $68.84 \%$. The lowest value is between secondary forest and oil palm plantation with $39.35 \%$.

From the data above, it can be concluded that two lands had same criteria of Collembola and one is not because both of them had value more than 50\%. According to Kendeigh (1980), if a community that said the same must has value of similarity index value more than $50 \%$.

\section{Conclusions and Recommendations}

Based on all the data above, it can take a conclusion that Collembola diversity in these belongs to medium level and had the same level of similarity. In this study, there are needed some further research like to find out about how the Collembola behavior in the nature, reproduction behavior of Collembola in this area and others.

\section{Acknowledgements}

I would like to thank to Prof. Dr. Yayuk Rahayuningsih Suhardjono at the Zoological Laboratory-Indonesia Science Institute who has given me advised for identification sample of Collembola.

\section{References}

[1] Barnes BV, Donald RZ, Shirley RD, and Stephen HS. Forest Ecology, 4th Edition. New York: Jhon Wiley and Sons Inc, 1997. 
[2] Ganjari, EL.Species Richness of Collembola at Verkomposting Habitat. Jurnal of Universitas Katolik Widya Warta Madiun. 2012, 1, 0854-1981.

[3] Juceviva E and Melecis V. Long-term effect of climate warning on forest soil Collembola. Journal of Acta Zool Lituanica. 2005; 15: 124-126

[4] Kendeigh SC. Ecology with Special Reference to Animal and Man. New Delhi: Prentice Hall of India. Private Limited, 1980.

[5] Magurran AE. Measuring Biological Diversity. Blackwell Publishing. Ltd, 2004.

[6] Odum EP. Fundamentals of Ecology. Third edition. Yogyakarta, 1998. Gadjah Mada University Press.

[7] Rizali A, Buchori D and Triwidodo H. Diversity Insect pada lahan persawahan - tepi Hutan: Indikator untuk Kesehatan Lingkungan. Hayati. 2002. 9 (2).

[8] Russel D, Hauth JA and Fox O. Community Dynamics of Soil Collembola in Floodplains of the upper Rhine Valley. Pedobiologia. 2004. 48: 527-536.

[9] Suhardjono Y R, Deharveng L and Bedos A. Collembola (Springtails). Bogor: Vegamedia. 2012.

[10] Trimurti S. Beberapa Kelompok Fauna Tanah Yang Tertangkap Pada Serasah Dan Dalam Tanah Di Zona Koleksi Hutan Alam Kebun Raya Unmul Samarinda. Mulawarman Scientifie. 2010. 9(1): $1412-498 x$

\footnotetext{
*Corresponding author.

E-mail address: febriyansyah.ok87@gmail.com
} 